\title{
Location and Anatomy of Nodules on Alnus maritima Subjected to Flooding
}

\author{
Heidi A. Kratsch and William R. Graves \\ Department of Horticulture, Iowa State University, Ames, IA 50011-1100
}

ADDITIONAL INDEX WORDS. seaside alder, Frankia, flood tolerance, symbiosis, oxygen, wetland, actinorhizal

\begin{abstract}
Although many species of Alnus Miller grow in wet soils, none is as closely associated with low-oxygen, waterlogged soils as Alnus maritima (Marsh.) Muhl. ex Nutt. (seaside alder). An actinorhizal species with promise for use in horticultural landscapes, land reclamation, and sustainable systems, $A$. maritima associates with Frankia Brunchorst, thereby forming root nodules in which gaseous nitrogen is fixed. Our objective was to determine how root-zone moisture conditions influence the occurrence, location, and anatomy of nodules on $\mathrm{A}$. maritima. Plants of Alnus maritima subsp. maritima Schrader and Graves were established in root zones with compatible Frankia and subjected to four moisture regimens (daily watered/drained, partially flooded, totally flooded, and totally flooded with argon bubbled through the flood water) for 8 weeks. Oxygen content of the root zone, number and location of nodules on root systems, and dry weight and nitrogen content of shoots were determined. Root-zone oxygen content ranged from $17.3 \mathrm{kPa}$ for daily watered/drained plants to $0.9 \mathrm{kPa}$ for argon-treated plants. Across all treatments, $87 \%$ of the nodules were within the upper one-third $(4 \mathrm{~cm})$ of the root zone. Although shoot dry weights of daily watered/drained and partially flooded plants were not different, daily watered/drained plants had more nitrogen in their leaves (2.53 vs. $2.21 \mathrm{mg}^{-\mathrm{g}^{-1}}$ ). Nodulation occurred in all treatments, but nodules on totally flooded roots (with or without argon) were limited to a single lobe; in contrast, multilobed nodules were prevalent on partially flooded and daily watered/drained plants. Frankia infection within submerged nodule lobes was limited to one or two layers of cortical cells. Submerged nodules developed large air spaces between cortical cells, and phenolic-containing cells appeared to inhibit Frankia expansion within the nodule. These data suggest that access to root-zone oxygen is critical to the Frankia-A. maritima subsp. maritima symbiosis, and that plants of this subspecies in the drained soils of managed landscapes may benefit more than plants in native wetland habitats from nodulation and nitrogen fixation.
\end{abstract}

Alnus maritima is a rare shrub unique among Alnus spp. for its natural occurrence exclusively in waterlogged soils (Schrader and Graves, 2002). This species is indigenous to only three disjunct locations in North America. It is found in and along rivers and streams in Oklahoma and on the Delmarva Peninsula, and in one swamp in Georgia (Schrader and Graves, 2003). Like other Alnus spp. (Bond, 1956), A. maritima forms symbioses with the nitrogenfixing bacterium Frankia (Stibolt, 1978). Symbiotic interactions culminate in formation of root nodules, a developmental process that is susceptible to irradiance (Hughes et al., 1999), temperature, $\mathrm{pH}$, and nutrient status of the root zone (Quispel, 1958).

Alnus maritima tolerates several abiotic stressors, including cold (Schrader and Graves, 2003), drought (Graves et al., 2002; Schrader et al., 2004), and to a limited extent, salt (Graves and Gallagher, 2003). The species shows great potential for use in land reclamation, sustainable systems, and other applications through which its capacity to improve soil by fixing atmospheric nitrogen can be especially beneficial. Understanding the factors that foster or limit growth of A. maritima would not only be of practical value but would facilitate efforts to preserve the species in its native habitat. All states where A. maritima is native consider the species rare, threatened, or imperiled (Schrader and Graves, 2002).

Hypoxia created by waterlogged soils presents a challenge for A. maritima roots and for Frankia because they both require oxygen to respire. Nodule occurrence (Schwintzer and Lancelle,

Received for publication 18 Dec. 2003. Accepted for publication19 May 2004 This project was supported by the Iowa Agriculture and Home Economics Experiment Station and State of Iowa funds through the Hatch Act. We would like to express our appreciation to Richard Gladon for his assistance with experimental design; and to Harry Horner, Tracy Pepper, and Rosanne Healy for assistance with preparation of materials for microscopy.
1983 ) and anatomical adjustments (Silvester et al., 1988) to low oxygen have been studied in Myrica spp., another actinorhizal genus of plants that occupies oxygen-poor soils. Whole-plant responses to flooding have been described for the more common Alnus spp. and include adventitious rooting and hypertrophied nodule and stem lenticel formation (Batzli and Dawson, 1997; Gill, 1975; McVean, 1956). The impact of flood-induced hypoxia on nodule occurrence in Alnus spp. and on nodule anatomy in $A$. maritima has not been investigated. Our objective was to determine whether flooding affects the location of nodules within the root system of potted A. maritima, the anatomy of nodules, and Frankia survival. We conducted this research with plants grown from seeds collected on the Delmarva Peninsula. This population, recently named A. maritima subsp. maritima (Schrader and Graves, 2002), was studied because the Plant Materials Center of the U.S. Dept. of Agriculture-Natural Resources Conservation Service (Cape May, N.J.) has expressed an interest in using it for conservation plantings.

\section{Materials and Methods}

\section{Plant growth and development}

Plant Materials. Alnus maritima subsp. maritima was propagated from seed collected in Dorchester Co., Md. Seeds were surface-sterilized in 10\% commercial bleach for 2 min; rinsed in distilled, deionized water; and cold-stratified at $4{ }^{\circ} \mathrm{C}$ for 3 weeks. Seeds were sown in plastic pots (top diameter $=11.5 \mathrm{~cm}$, height $=9.5 \mathrm{~cm}$, volume $=929 \mathrm{~cm}^{3}$ ) filled with an unpasteurized mix of 1 soil (sandy clay loam obtained in Iowa and confirmed in preliminary trials to contain Frankia compatible with A. maritima) : 2 perlite : 2 sphagnum peat (by volume). The $\mathrm{pH}$ of the substrate was 6.0. The pots were held on a greenhouse bench 
where 16-h photoperiods were provided by using incandescent lamps. Seedlings were irrigated with tap water daily and fertilized three times per week with Peters Excel All-Purpose and Cal-Mag (17N-2.2P-13.3K) (Scotts-Sierra Horticultural Products, Marysville, Ohio), providing nitrogen at $11 \mathrm{~mm}$ to prevent nodulation before treatments began. Nitrogen was $13.8 \% \mathrm{NH}_{4}{ }^{+}, 73.7 \% \mathrm{NO}_{3}{ }^{-}$, and $12.5 \%$ urea. Three weeks after germination, seedlings were transferred to individual plastic pots (top diameter $=12.5 \mathrm{~cm}$, height $=12.5 \mathrm{~cm}$, volume $=1406 \mathrm{~cm}^{3}$ ).

Treatments AND EXPERIMENTAL DESIGN. Forty-four uniform seedlings that were 4 months old were considered experimental units and assigned randomly to one of four treatments $(n=11)$ : daily watered/drained (positive control), partial flood, total flood, and total flood/argon (negative control). The pot of each seedling was placed in an opaque plastic container (top diameter $=14 \mathrm{~cm}$, height $=15 \mathrm{~cm}$, volume $\left.=2520 \mathrm{~cm}^{3}\right)$. Daily watered $/$ drained plants were irrigated daily with $400 \mathrm{~mL}$ of tap water, and pots were allowed to drain outside their external container such that no free water accumulated within the external container. Partially flooded conditions were imposed by maintaining $1.5 \mathrm{~cm}$ of tap water in the bottom of the external container. Totally flooded conditions were maintained by keeping the external container filled with tap water and a water column $2 \mathrm{~cm}$ above the solid matrix. Total flood/argon treatment consisted of bubbling argon into totally flooded containers by using a gas-dispersion stone at the bottom of the external container. Argon was chosen over nitrogen as an inert gas for displacement of oxygen because of the potential for nitrogen to confound nodulation data. The gas-dispersion stones were connected to a cylinder of compressed argon via smallbore tubes attached to a copper manifold. Plants were held on a greenhouse bench where 16-h photoperiods were achieved by using two 400-W, high-pressure sodium lamps. Treatments were initiated 5 June 2002, and plants were harvested 8 weeks later. We used a data logger (CR23X; Campbell Scientific, Logan, Utah) equipped with appropriate sensors to monitor the environment during treatments and found air temperature averaged $24^{\circ} \mathrm{C}$ (range 21 to $35^{\circ} \mathrm{C}$ ), mean relative humidity was $67 \%$ (range $32 \%$ to $95 \%$ ), and the maximum photosynthetically active radiation on cloudless days was $690 \mu \mathrm{mol} \cdot \mathrm{m}^{-2} \cdot \mathrm{s}^{-1}$.

Weights of all leaf blades, stems, and petioles were determined after tissues dried for $3 \mathrm{~d}$ at $67^{\circ} \mathrm{C}$. Dried leaf blades were ground in a tissue homogenizer and analyzed for nitrogen content by the Kjehldahl method. Oxygen content of each root zone was measured, after 4 and 8 weeks of treatment, with a needle oxygen electrode connected to a chemical microsensor(Diamond General Development Corp., Ann Arbor, Mich.). Measurements were taken within $1 \mathrm{~h}$ after irrigation of the plants, and the electrode was placed $4 \mathrm{~cm}$ below the surface of the solid matrix $(6 \mathrm{~cm}$ below the surface of the water for flooded plants). We used the general linear models (GLM) procedure of SAS/STAT, version 8.1 , to examine the effect of irrigation treatments on the dependent variables, and when appropriate, Fisher's least significant difference (LSD) test was used at $P \leq 0.05$ to separate irrigation treatment means.

\section{Nodule occurrence and location}

We recorded the number of nodules on each root system as plants were harvested. Each nodulation event, whether it resulted in a single nodule lobe or a cluster of lobes, was counted as one nodule. Roots of each plant were washed thoroughly and placed against a grid to determine the location of each nodule within the vertical profile of each root system (Fig. 1). Area 1 on the grid represented the lowest $1.5 \mathrm{~cm}$ of each root zone and corresponded to the saturated portion of root zones of the partially flooded plants. The upper boundary for area 2 represented the vertical middle of the root zone for partially flooded and daily watered/drained

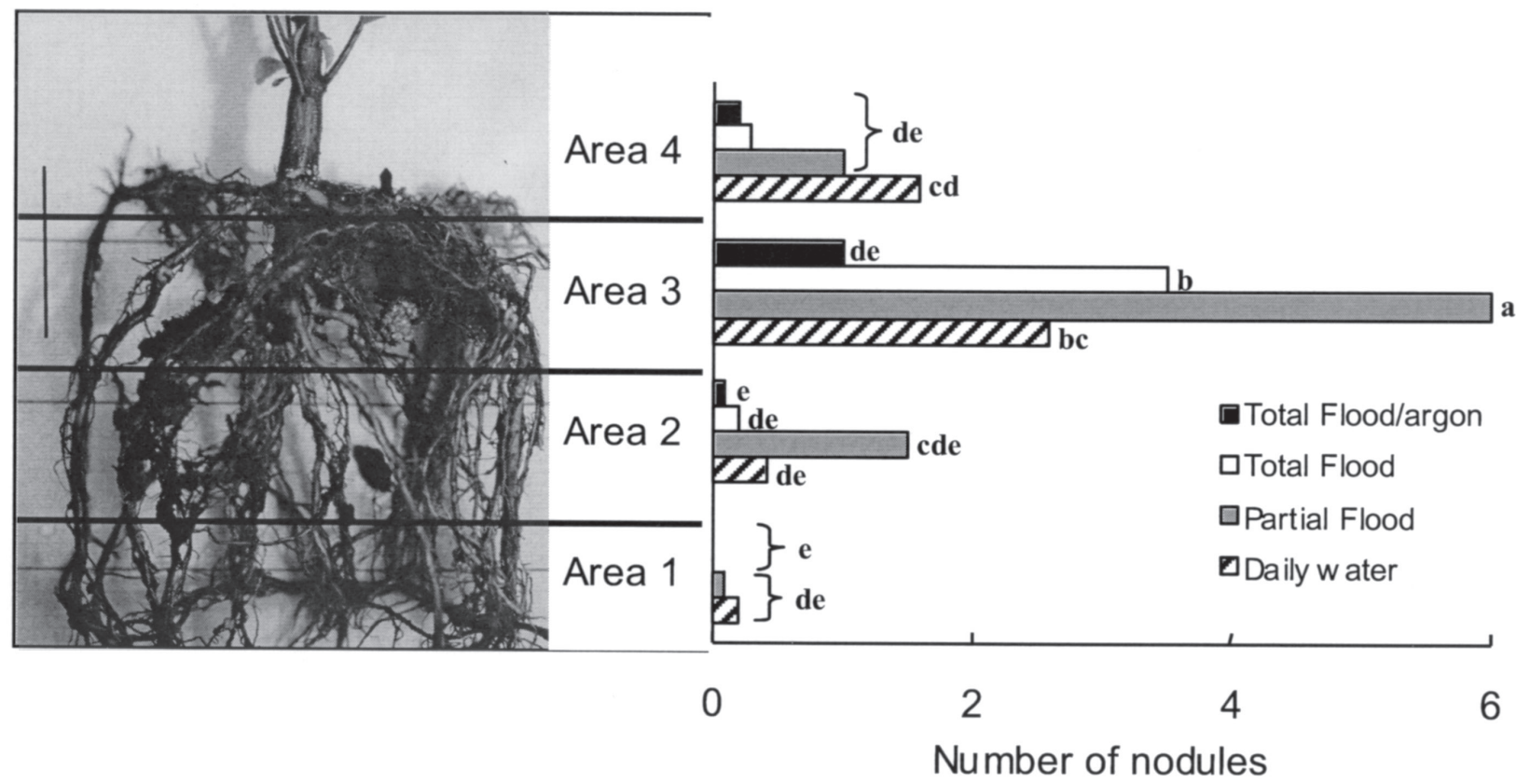

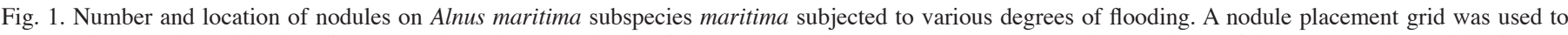

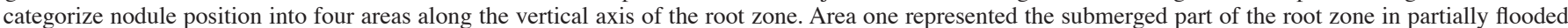

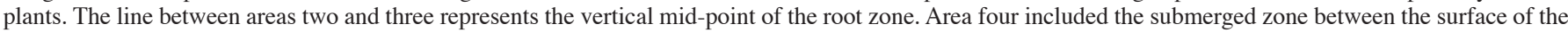

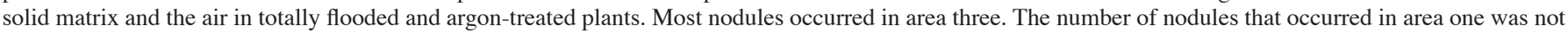
different from zero. Bars followed by the same letter are not different at $P \leq 0.05$ according to Fisher's least significant difference test. Sidebar is 4 cm. 
plants. Area 3 corresponded to the upper $4 \mathrm{~cm}$ of the solid matrix in each root zone, and area 4 represented the zone above the solid surface, which was filled with either water or air depending upon the treatment. We also used GLM and Fisher's LSD to examine variation in the number of nodules that formed.

\section{Microscopy}

All nodules from the three most morphologically representative plants from each treatment were harvested for chemical fixation. Nodules were fixed in a solution of $2 \%$ glutaraldehyde and $2 \%$ paraformaldehyde in a 0.1-M sodium cacodylate buffer at $\mathrm{pH}$ 7.2. While in fixative, nodule clusters were separated into individual lobes. Large-diameter lobes were dissected longitudinally, and smaller lobes were left whole to obtain a uniform sample size of $\leq 3 \mathrm{~mm}^{3}$. All tissues were stored at $4{ }^{\circ} \mathrm{C}$ overnight in fresh fixative. After rinsing with buffer, the tissue was post-fixed in $1 \%$ aqueous osmium tetroxide and dehydrated through a graded series of ethanols. The tissue was stained en bloc with 5\% aqueous uranyl acetate and embedded in Spurr's resin (Spurr, 1969). Thick sections $(1 \mu \mathrm{m})$ were stained with toluidine blue and viewed with an Olympus Bx40 (Olympus Optical, Tokyo) compound light microscope. Thin sections $(55 \mathrm{~nm})$ were stained with lead acetate and viewed with a JEOL 1200Ex (JEOL USA, Peabody, Mass.) scanning transmission electron microscope operating at $80 \mathrm{kV}$. Sections from at least three nodules from each treatment were observed. Frankia viability was assessed by using microscopy to verify the presence of intact Frankia hyphae and/or vesicles within the nodule cortical cells.

\section{Results}

\section{Plant growth and development}

After 8 weeks, the leaves of all totally flooded plants (with and without argon) appeared mottled and chlorotic, and shoots of plants in those two treatments were multi-stemmed and stunted (Fig. 2A and B). No dieback of shoots or treatment-induced defoliation was noted. Proliferation of lenticels occurred at the root collar of plants in the total-flood treatments with and without argon; the lenticel tissue on the stems of argon-treated plants was long $(2 \mathrm{~cm})$, brittle, and easily broken (Fig. 2C). Nodules from these plants also developed hypertrophied lenticels along the surface of the periderm (not shown). Partially flooded plants were tall and single-stemmed, and the shoot tissue appeared healthy and green. Shoots of plants that were watered and drained daily were morphologically similar to shoots of partially flooded plants (Fig. 2A), except that shoots of drained plants appeared darker green than those of partially flooded plants. Root-zone oxygen content ranged from $<1 \mathrm{kPa}$ for the argon-treated plants to $>17 \mathrm{kPa}$ for the daily watered/drained plants (Table 1).

Nitrogen accumulation in leaves of daily watered/drained plants was $14 \%$ greater than that of partially flooded plants, despite the fact that partially flooded plants formed over $70 \%$ more nodules (Table 1). Totally flooded plants accumulated just over half as much nitrogen as daily watered/drained plants despite a similar number of nodules among plants in the two treatments. Daily watered/drained and partially flooded plants had similarly high shoot dry weight. The combined mean shoot dry weights of plants in those two treatments was nearly twice that of plants in the two total-flood treatments (Table 1).

\section{Nodule occurrence and location}

Nodules of partially flooded and daily watered/drained plants appeared consistently larger than those from totally flooded and
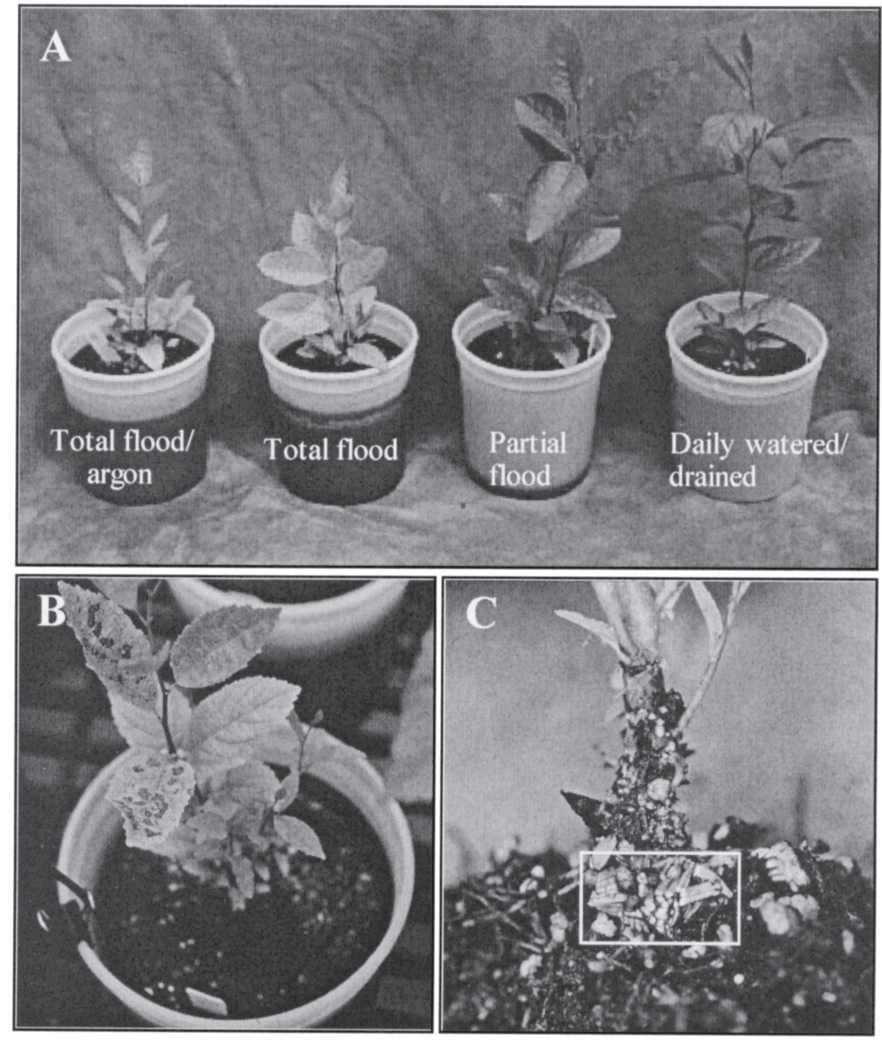

Fig. 2. Effects of various degrees of flooding on seedlings of Alnus maritima subsp. maritima. (A) Shoots of partially flooded plants were similar in size to shoots of plants that were watered daily and drained. (B) Shoots of plants with roots that were totally flooded in water gassed with argon were stunted, and the leaves appeared mottled and chlorotic. $(\mathbf{C})$ Long $(2 \mathrm{~cm})$, fragile protuberances grew out from the lenticels at the base of argon-treated plants.

Table 1. Root-zone oxygen $\left(\mathrm{O}_{2}\right)$, leaf nitrogen $(\mathrm{N})$ accumulation, number of root nodules per plant, and shoot dry weight of Alnus maritima subsp. maritima grown in a greenhouse for 8 weeks in pots with four irrigation regimens. Germinated seedlings were watered daily, and nitrogen fertilizer was provided three times weekly for 4 months before treatment. Treatments began 5 June 2002.

\begin{tabular}{|c|c|c|c|c|}
\hline $\begin{array}{l}\text { Root-zone } \\
\text { moisture } \\
\text { treatment }\end{array}$ & $\begin{array}{c}\text { Root- } \\
\text { zone } \\
\mathrm{O}_{2}(\mathrm{kPa})^{\mathrm{y}}\end{array}$ & $\begin{array}{c}\text { Total } \\
\text { leaf } \mathrm{N} \\
\left(\mathrm{mg} \cdot \mathrm{g}^{-1}\right)\end{array}$ & $\begin{array}{c}\text { No. of } \\
\text { nodules/ } \\
\text { plant }\end{array}$ & $\begin{array}{c}\text { Shoot } \\
\text { dry } \\
\text { wt (g) }\end{array}$ \\
\hline $\begin{array}{l}\text { Watered daily, } \\
\text { drained }\end{array}$ & $17.3 \mathrm{a}^{\mathrm{x}}$ & $25.3 \mathrm{a}$ & $4.8 \mathrm{~b}$ & $2.55 \mathrm{a}$ \\
\hline Partial flood & $13.1 \mathrm{~b}$ & $22.1 \mathrm{~b}$ & $8.3 \mathrm{a}$ & $2.70 \mathrm{a}$ \\
\hline Total flood & $1.2 \mathrm{c}$ & $14.1 \mathrm{c}$ & $3.9 \mathrm{bc}$ & $1.40 \mathrm{~b}$ \\
\hline $\begin{array}{l}\text { Total flood } \\
\text { with argon }\end{array}$ & $0.9 \mathrm{c}$ & $13.4 \mathrm{c}$ & $1.3 \mathrm{c}$ & $1.33 \mathrm{~b}$ \\
\hline
\end{tabular}

${ }^{\mathrm{z}} \mathrm{n}=11$ seedlings per treatment

yValues represent the average of two measurements per plant, after 4 and 8 weeks of treatment.

xMeans within columns followed by the same letter are not different at $P \leq 0.05$ according to Fisher's least significant difference test.

argon-treated plants. Nodules as large as $1 \mathrm{~cm}$ diameter were found on roots of partially flooded and daily watered/drained plants. Such nodules were often multilobed. Nodules on the roots of totally flooded and argon-treated plants were rarely multilobed and were not $>3 \mathrm{~mm}$ diameter. Some nodules that occurred in area 4 showed green and red pigmentation around the apex of nodule lobes. 
Roots of partially flooded plants formed more than twice the number of nodules as the average number on roots of plants in the other three treatments (Table 1). Analysis of nodule-count data showed an interaction between irrigation treatment and root-zone area. The particularly strong influence of irrigation treatment within area 3 (Fig. 1) accounted for the interaction. Eighty-seven percent of the total number of nodules occurred within the upper $4 \mathrm{~cm}$ of the soil/air/water interface, primarily within area 3 . Area 3 was the only zone in which totally flooded and argon-treated plants produced a statistically significant number of nodules (data not shown). Nodulation in area 1 was sparse; no nodules formed in area 1 for plants in both total flood treatments, and nodule development on plants in the other two treatments was so restricted that it was not significant statistically. Across all treatments, nodules frequently developed at the periphery of the root zone. They were also noted near drainage holes of the pots in the root zone of daily watered/drained plants.

\section{Microscopy}

Representative mature Frankia cells within nodules from all four treatments were intact and often surrounded by uniformly spherical vesicles (Fig. 3). Cortical cells in nodules from both partially flooded (Fig. 3A) and daily watered/drained (not shown) plants were densely arranged, with few air spaces between them. Infected cells were large, often multivacuolate, and filled with Frankia hyphae and/or mature Frankia vesicles. Uninfected cells were smaller and entirely filled with a single vacuole; starch grains were often present in these cells (not shown).

Air spaces between cortical cells in totally flooded (Fig. 3B) and argon-treated (Fig. 3C) nodules were large and prominent. Areas of Frankia infection were only one or two cell layers thick in these nodules, and they were bounded by rows of uninfected cells, the vacuoles of which were filled with darkly staining phenolic compounds. Phenolic compounds were particularly prominent in argon-treated nodules, and this often interfered with obtaining intact tissue sections. The viability of Frankia cells within totally flooded nodules was confirmed by electron microscopy (Fig. 4). In addition to observing intact Frankia vesicles and hyphae, the cytoplasm of infected cortical cells in totally flooded nodules was turgid and filled with mitochondria (Fig. 4A and B), ribosomes, and other organelles (not shown).

\section{Discussion}

Our results indicate that plants of A. maritima subsp. maritima grown under waterlogged root-zone conditions typical of native habitats are limited in their capacity to fix nitrogen. Further, these results suggest that nodulation and nitrogen fixation by this subspecies may be increased in managed environments where soils are not as frequently waterlogged and are likely to contain more oxygen than do soils where plants are indigenous. The potential use of A. maritima subsp. maritima as a nitrogen-fixing actinorhizal subspecies should not be restricted to soils that drain well, however, because nodule formation and Frankia survival are not inhibited by flooding. Our data show that the number of nodules that develop on a plant of A. maritima subsp. maritima is not a reliable indicator of the amount of foliar nitrogen that can accumulate (Table 1). For other actinorhizal species, total nodule mass, but not total nodule number, per plant remains relatively constant (Nelson, 1983; Tjepkema et al., 1986), and development of ineffective (non-nitrogen-fixing) nodules has been reported (Berry and Sunell, 1990). Therefore, nodule counts should be used only in conjunction with other measures as an indicator of nitrogen fixation.

Our data on how flooding affects shoot dry weight are consistent with data of Schrader et al. (2004), who found that A. maritima survives extended periods of total root-zone inundation and thrives with a portion of its root zone flooded. The flood-induced symptoms of stress we observed were similar to those of other Alnus spp., but they were delayed relative to those species and occurred only under severely flooded conditions. McVean (1956) reported adventitious rooting in native stands of Alnus glutinosa (L.) Gaertn., and the appearance of "powdery lenticellular tissue" on the stem base and on the outer periderm of nodules on trees in wet soils that were not inundated. Many trees in this stand died when the roots were entirely submerged during a flooding event (Clarke, 1925), and nodules were not observed on roots that were submerged. Batzli and Dawson (1997) observed hy-
A

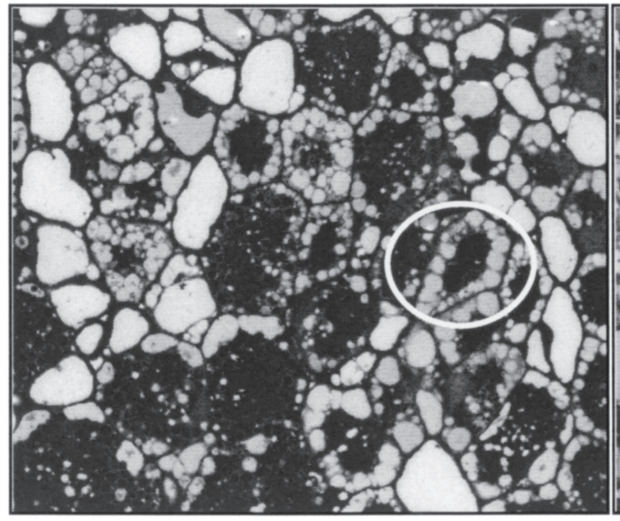

B

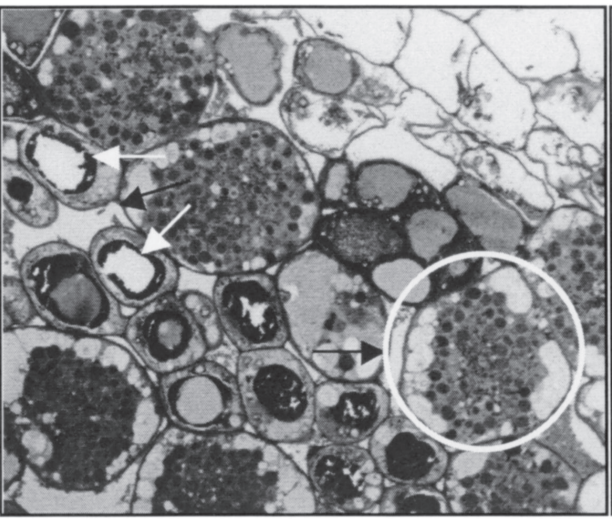

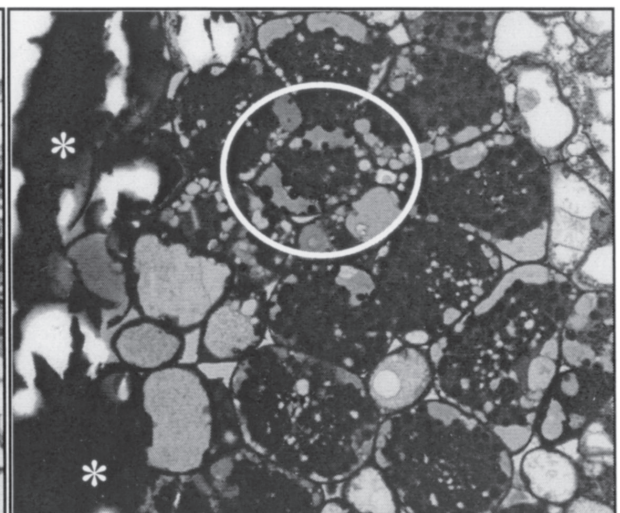

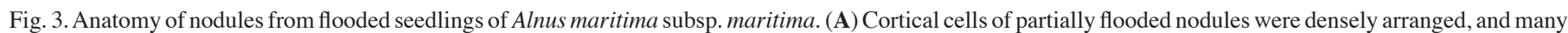

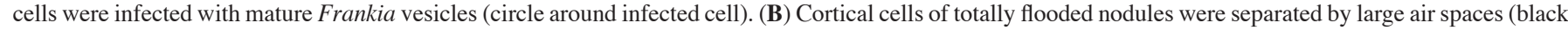

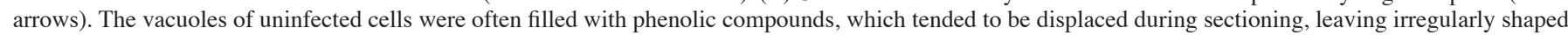

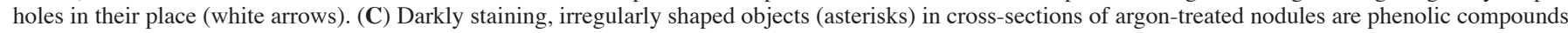
that became dislodged during sectioning. Frankia infection throughout the nodule was inhibited in totally flooded and argon-treated plants. Bar is $50 \mu \mathrm{m}$. 

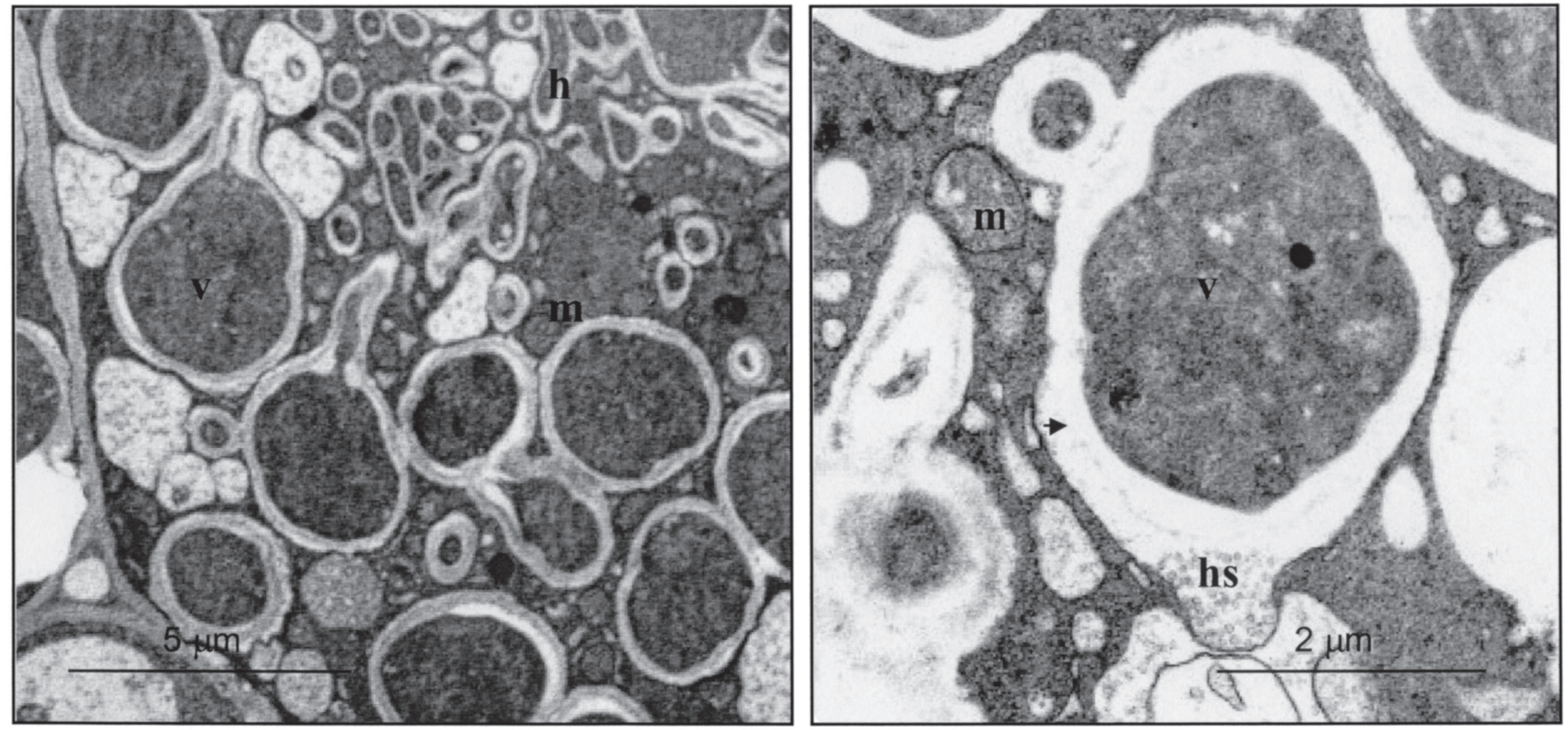

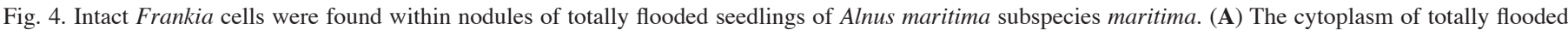

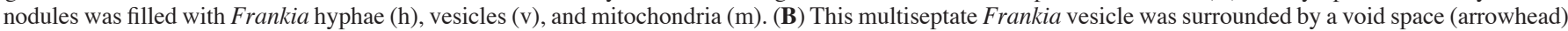
and was within close vicinity of a mitochondrion. A hyphal strand (hs) was emerging from the bottom of the vesicle.

pertrophied lenticel tissue after flooding Alnus rubra Bong. and Alnus viridis ssp. sinuata (Regel) Löve and Löve for 4 and 5 d, respectively; adventitious rooting of $A$. rubra was observed after 8 d. Conversely, 2-year-old $A$. rubra saplings were killed by $<1$ week of static flooding with water levels to or above the soil surface (Ewing, 1996). In contrast, A. maritima had not developed observable symptoms after at least 4 weeks of total flooding. In a recent comparison with several other Alnus spp., $A$. maritima was among the most tolerant of soil-moisture extremes (Schrader et al., 2004).

Myrica gale L. occurs in waterlogged soils much like those in the native habitats of A. maritima. M. gale shows a growth response to flooding similar to that of A. maritima subsp. maritima. Shoot height and dry weight of $M$. gale were greatest when root zones were subjected to partial flooding (Schwintzer and Lancelle, 1983). Partially flooded plants of $M$. gale also had the greatest nodule biomass. We did not determine nodule biomass, but plants of partially flooded A. maritima subsp. maritima formed the most nodules (Table 1), and many of these nodules were as large as those on roots of daily watered/drained plants. Both $M$. gale and A. maritima subsp. maritima are capable of developing nodules on submerged roots, and these two taxa may have evolved some of the same mechanisms for controlling the oxygen environment within roots and nodules. We are confident that plants of A. maritima subsp. maritima were without nodules before flooding was imposed because we repeatedly observed complete inhibition of nodulation by nitrogen provided at the concentrations we applied before treatments began.

We observed that most nodules occurred within the upper one-third of the root zone. This is consistent with observations of nodule formation in A. glutinosa (McVean, 1956), and in some other actinorhizal species: Colletia Comm. ex Juss. (Rhamnaceae)
(Bond and Becking, 1982) and the western North American shrubs Cowania stansburiana Torr., Purshia tridentata (Pursh) DC., Purshia glandulosa Curran, and Cercocarpus ledifolius Nutt. (Rosaceae) growing in native stands (Nelson, 1983). These workers found nodulation primarily within the upper part of the root system and close to the soil surface. On the other hand, Schwintzer and Lancelle (1983) reported differences in the distribution of nodules within the root zone of $M$. gale depending on whether plants were grown in peat or sand at varying water-table depths. Nelson (1983) found uniform nodule distribution throughout root systems of containerized $C$. stansburiana grown in 1 native soil (texture not reported) : 1 silica sand-vermiculite (by volume). Such differences may be due to the various root-zone conditions to which plants in these experiments were exposed. The interaction between irrigation treatment and root-zone area for our nodule-count data illustrates that root-zone moisture conditions may be among the important determinants of nodule distribution. It remains uncertain whether our irrigation regimens affected nodule formation directly. Differences in $\mathrm{pH}$ or other root-zone conditions associated with the four treatments we applied may have influenced nodule distribution indirectly via influences on root growth in the four areas we defined. We did not partition root dry weight in the four areas, but compared to plants in other treatments, partially flooded plants appeared to have more roots distributed in the lower portion of the root zone and relatively few roots in area 4 . This may explain the relatively poor nodulation in area 4 of partially flooded plants (Fig. 1), and the poor nodulation where roots appeared to proliferate in area 1 suggests that nodule number was not solely a function of root distribution.

Adjustments to low-oxygen peat soils of $M$. gale include upward-growing nodule roots (Schwintzer and Lancelle, 1983), extensive air spaces between cortical cells (Silvester et al., 1988), 
and the occurrence of hemoglobin within infected cortical cells (Pathirana and Tjepkema, 1995). Likewise, we found that totally flooded and argon-treated nodules had large air spaces between cortical cells (Fig. 3B and C). These, in combination with the lenticels on the outer periderm, could act as a channel for the diffusion of oxygen into the symbiosis. Interestingly, these adjustments in $M$. gale are not sufficient to support optimal levels of nitrogen fixation when nodules are flooded (Tjepkema et al., 1986). We conclude that this also is the case for A. maritima subsp. maritima because totally flooded plants accrue less nitrogen than do daily watered/drained and partially flooded plants (Table 1).

The fact that Frankia proliferation is limited within the nodules of totally flooded and argon-treated plants of A. maritima subsp. maritima supports this conclusion. These nodules accumulated greater amounts of phenolic compounds, and the areas of Frankia infection appeared to be restricted by closely arranged rows of cells containing these compounds (Fig. 3B and C). Flavonoids, a class of phenolic compounds, were extracted from $A$. rubra seeds and influenced nodulation of A. rubra by Frankia (Benoit and Berry, 1997), and phenolic-containing cells compartmentalized areas of Frankia infection within nodules of Casuarina glauca Sieber (Laplaze et al., 1999). These studies suggest a role for flavonoids in regulating interactions between Frankia and its plant host. It is feasible that, in our study, phenolic compounds may have limited the spread of Frankia within totally flooded and argon-treated nodules, presumably to prevent Frankia from becoming parasitic by consuming excessive carbon under growthlimiting conditions (Markham, 1996).

We have provided the first evidence that nodules with viable Frankia can form in partially flooded and totally flooded root zones. Yet our data also indicate that nodule formation and function are sensitive to inundation. Therefore, future workers should focus on defining the optimal root-zone oxygen concentration for nitrogen fixation by the symbiosis of Frankia-A. maritima subsp. maritima. Despite restrictions over their spread, Frankia and the cells they inhabit were viable under flooded conditions. This suggests that these plants retained the capacity to recover from their flooded state, and that plants in their native habitat may have mechanisms for coping with periods of flooding. Indeed, some A. maritima subsp. maritima occur in waterways that are subject to tidal changes in water depth (Graves and Gallagher, 2003). Nodules on these plants may be exposed periodically to concentrations of oxygen that facilitate nitrogen fixation. Future studies could examine the impact of changing water levels on nodule occurrence and Frankia nitrogen fixation.

\section{Literature Cited}

Batzli, J.M. and J.O. Dawson. 1997. Physiology and morphological responses of red alder and sitka alder to flooding. Physiol. Plant. 99:653-663.

Benoit L.F. and A.M. Berry. 1997. Flavonoid-like compounds from seeds of red alder (Alnus rubra) influence host nodulation by Frankia (Actinomycetales). Physiol. Plant. 99:588-593.

Berry, A.M. and L.A. Sunell. 1990. The infection process and nodule development, p. 61-81. In: C.R. Schwintzer and J.D. Tjepkema (eds.). The biology of Frankia and actinorhizal plants. Academic, San Diego.

Bond, G. 1956. Evidence for fixation of nitrogen by root nodules of alder (Alnus) under field conditions. New Phytol. 55:147-153.

Bond, G. and J.H. Becking (1982) Root nodules in the genus Colletia. New Phytol. 90:57-65.

Clarke, W. 1925. In Breckland wilds. Heffer, Cambridge, U.K.

Ewing, K. 1996. Tolerance of four wetland plant species to flooding and sediment deposition. Environ. Expt. Bot. 36:131-146.

Gill, C.J. 1975. The ecological significance of adventitious rooting as a response to flooding in woody species, with a special reference to Alnus glutinosa (L.) Gaertn. Flora 164:85-97.

Graves, W.R. and J.R. Gallagher. 2003. Resistance to salinity of Alnus maritima from disjunct wetlands: symptoms of salt injury, comparison to other shrubs, and effect of inundation. Wetlands 23:394-405.

Graves, W.R., M.A. Kroggel, and M.P. Widrlechner. 2002. Photosynthesis and shoot health of five birch and four alder taxa after drought and flooding. J. Environ. Hort. 20:36-40.

Hughes, M., C. Donnelly, A. Crozier, and C.T. Wheeler. 1999. Effects of the exposure of roots of Alnus glutinosa to light on flavonoids and nodulation. Can. J. Bot. 77:1311-1315.

Laplaze, L., H. Gherbi, T. Frutz, K. Pawlowski, C. Franche, J.-J. Macheix, F. Auguy, D. Bogusz, and E. Duhoux. 1999. Flavan-containing cells delimit Frankia-infected compartments in Casuarina glauca nodules. Plant Physiol. 121:113-122.

Markham, J.H. 1996. A field test of the coevolution between red alder and Frankia populations. PhD Diss., Univ. of British Columbia, Vancouver.

McVean, D.N. 1956. Ecology of Alnus glutinosa (L.) Gaertn: IV. Root system. J. Ecol. 44:219-225.

Nelson, D.L. 1983. Occurrence and nature of actinorhizae on Cowania stansburiana and other Rosaceae. U.S. Dept. Agr. For. Serv. Gen. Tech. Rpt. INT 152:225-239.

Pathirana, S.M. and J.D. Tjepkema. 1995. Purification of hemoglobin from the actinorhizal root nodules of Myrica gale L. Plant Physiol. 107:827-831.

Quispel, A. 1958. Symbiotic nitrogen fixation in non-leguminous plants. Acta Botanica Neerlandica 7:191-204.

SAS Institute. 1999. SAS/STATSoftware, Version 8.1, of the SAS System. Copyright 1999-2000. SAS Inst., Cary, N.C.

Schrader, J.A. and W.R. Graves. 2002. Infraspecific systematics of Alnus maritima (Betulaceae) from three widely disjunct provenances. Castanea 67:380-401.

Schrader, J.A. and W.R. Graves. 2003. Phenology and depth of cold acclimation in the three subspecies of Alnus maritima. J. Amer. Soc. Hort. Sci. 128:330-336.

Schrader, J.A., S.J. Gardner, and W.R. Graves. 2004. Resistance to water stress of Alnus maritima: Intraspecific variation and comparisons to other alders. Environ. Expt. Bot. (In press).

Schwintzer, C.R. and S.A. Lancelle. 1983. Effect of water-table depth on shoot growth, root growth, and nodulation of Myrica gale seedlings. J. Ecol. 71:489-501.

Silvester, W.B., J. Whitbeck, J.K. Silvester, and J.G. Torrey. 1988. Growth, nodule morphology, and nitrogenase activity of Myrica gale with roots grown at various oxygen levels. Can. J. Bot. 66:1762-1771.

Spurr, A.R. 1969. A low-viscosity epoxy resin embedding medium for electron microscopy. J. Ultrastructure Res. 26:31-34.

Stibolt, V.M. 1978. The systematics and ecology of Alnus maritima Muhl. ex Nutt. (Betulaceae). MS Thesis, Univ. of Maryland, College Park.

Tjepkema, J.D., C.R. Schwintzer, and D.R. Benson. 1986. Physiology of actinorhizal nodules. Annu. Rev. Plant Physiol. 37:209-232. 